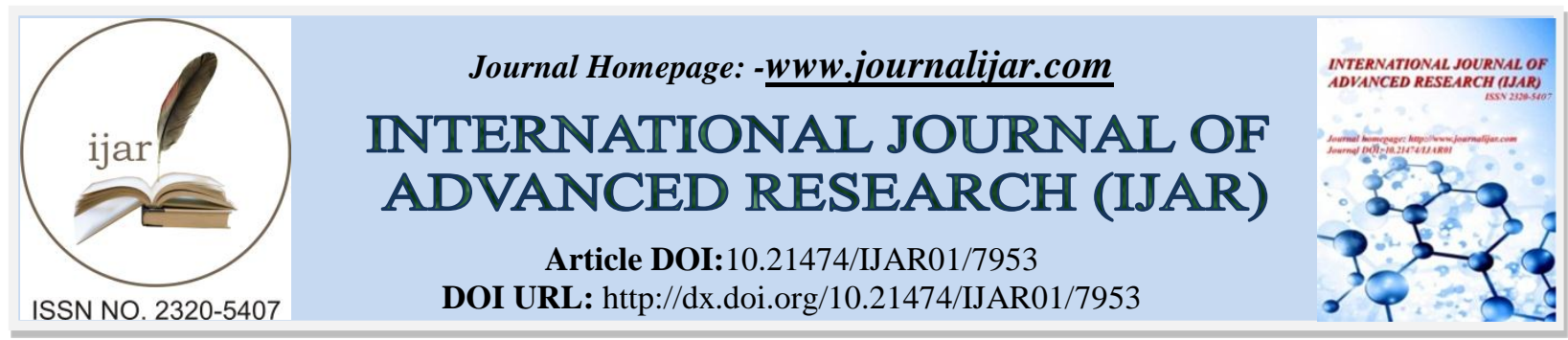

RESEARCH ARTICLE

\title{
"OBSTETRIC MANAGEMENT IN PRIMIGRAMS OF TERM OF BETWEEN 12 AND 16 YEARS IN THE GENERAL HOSPITAL OF CAMPECHE".
}

\author{
Betty Sarabia Alcocer ${ }^{1}$, Luis Alberto Núñez Oreza ${ }^{2}$, Betty Mónica Velázquez Sarabia ${ }^{3}$, Priscilla Karmina \\ Velázquez Sarabia ${ }^{4}$, Paulino Tamay Segovia ${ }^{2}$, Selene Blum Domínguez ${ }^{2}$, Patricia Margarita Garma Quen ${ }^{5}$, \\ Rafael Manuel de Jesús Mex Álvarez ${ }^{5}$ and Ángel Arturo Ake Ordoñez ${ }^{6}$. \\ 1. Faculty of Medicine of the Autonomous University of Campeche. \\ 2. Center for Biomedical Research. Autonomous University of Campeche. \\ 3. Doctor Surgeon graduated from the Faculty of Medicine of the U.A.C. \\ 4. Law graduate and researcher. \\ 5. Faculty of Biological Chemistry. \\ 6. Student of the Licentiate Medical Surgeon.
}

\section{Manuscript Info}

Manuscript History

Received: 17 August 2018

Final Accepted: 19 September 2018

Published: October 2018

Keywords:-

Primigestas, adolescents, obstetric management..

\section{Abstract}

A study was carried out where the records of primigrams of term from 12 to 16 years were reviewed, to determine which was the most frequent obstetric management in the resolution of their pregnancy. An observational, retrospective, descriptive and transversal design study was carried out; obtaining the data through the review of clinical files. The results showed that the main obstetric management in these patients was the completion of pregnancy by vaginal route with a total of 68 patients $(68 \%)$, while 32 patients showed a resolution by the abdominal route of their pregnancy (32\%). In addition, we can add that the most frequent age of pregnancy was 16 years with a total of 57 patients $(57 \%)$. While $68 \%$ of the study patients did not show complications at an early age for gestation. In conclusion, what we find in the literature in our environment still shows a tendency for the resolution of vaginal pregnancy in primigravid patients of early ages.

Copy Right, IJAR, 2018,. All rights reserved.

\section{Introduction:-}

Pregnancy in women under 16 years of age represents a problem of obstetric care due to the risks that these patients often cause, as well as being a serious public health problem, so we will begin by defining some important aspects.

Adolescence is a period of transition between childhood and adulthood. Its definition is not easy, since its characterization depends on a series of variables: ecological location (referred to the natural environment), socioeconomic stratum, ethnic origin and period of adolescence, among others. ${ }^{1}$

Recall that the sexual maturation of women begins at puberty, with the appearance of bodily changes, these changes precede the first menstruation that is the clearest sign and is an indication that the internal organs of reproduction are maturing. The chronological sequence of these changes culminates in obtaining the reproductive capacity which varies from one woman to another, the corporal manifestations such as the beginning of the development of the 
breasts, the appearance of pubic hair and the acceleration of the growth anteceden in a very variable, the actual start of menstruation.

Sexuality can be defined as the set of pleasurable activities related to genital activity. In psychoanalysis it has a broader meaning that goes beyond the purely genital and designates a series of activities that seek satisfaction through the different erogenous zones. ${ }^{2}$

Pregnancy is defined as the status of a woman after conception until the birth of the child. ${ }^{3}$

Adolescent pregnancy is a major public health problem, especially in girls under 16, both in developed and underdeveloped countries and is favored by causes, many of a psychosocial nature. ${ }^{4}$

Adolescents make up an important part of the world population, they represent between 20 and $25 \%$ of the global population number. According to figures reported by the United Nations Fund UNFPA ${ }^{5}$, teenage pregnancy represents just over $10 \%$ of all births in the world; it is said that they represent about 14,000,000 women between 15 and 20 years of age. In Mexico 70 out of every thousand adolescents are pregnant, compared to the rate of 50 per thousand of U.S. or France and Germany which is 9 and 4 respectively of each thousand. ${ }^{6}$

According to figures from the CONAPO in 2000 there were 366,000 births of adolescent women, obtaining a net figure of 1 pregnant adolescent for every 14 adolescents that exist in our country. ${ }^{7}$

In 2002, it is reported that each year 3,312,000 Latin American adolescents will complete their pregnancy. The number of abortions is ignored. However, in adolescence it is related to factors that include low socioeconomic level, family instability, initiation of sexual activity at an early age, lack of knowledge in sexual education and irresponsibility on the part of adolescents. We can also show that successive pregnancies in adolescents contribute to perpetuate the cycle of poverty and misery. ${ }^{8}$

In Mexico, approximately 700,000 women, under 20 years of age, are pregnant, of which $20.7 \%$ of the total are in the state. Campeche is number 2, being Nayarit the state with the highest number of pregnant adolescents $21 \%$; while the federal district has the lowest number with $13.2 \% .{ }^{9}$

Early motherhood is a multi-causal phenomenon involving social, economic and cultural factors. There has been much theorizing about the consequences that a pregnancy can have on an adolescent woman. From the biological point of view, it is said that there is a greater tendency to present hypertensive disease induced by pregnancy, threat of preterm delivery, a high incidence of cephalopelvic disproportion and a greater tendency to be born by cesarean section, as well as a greater presence of birth weight and finally a higher incidence of early neonatal death. It is also said that these women have a higher puerperal morbidity. ${ }^{10,11,12}$

\section{Material and methods:-}

The present study was carried out in an observational, descriptive, transversal and retrospective way, it was carried out in the General Hospital of Campeche "Dr. Álvaro Vidal Vera "in the city of San Francisco de Campeche, Campeche.

All the primiparous patients of 12 to 16 years of age served in the gynecology and obstetrics service for pregnancy completion during the study period from July to December 2017 were considered as the universe of study.

Regarding the population to be studied, primitive patients of 12 to 16 years of age served in said institution during the study period were considered.

The following inclusion criteria were used: primigravida patients from 12 to 16 years of age who did not show any complications of pregnancy and without preexisting pathologies.

As exclusion criteria for patients outside the established age ranges, patients from 12 to 16 years old who are not full-term primigravida, who enter the service due to pathologies unrelated to pregnancy, patients with persistent pathologies during pregnancy and patients with a diagnosis of death. fetal. 
The study was carried out from the collection of data from the records of statistical records of the Gynecology Service, as well as in the clinical files in the area of the hospital file, by means of a format attached to the end of the work.

The variables used as independent: Term pregnancy, primigravida, age; as dependent variable, delivery and cesarean section.

\section{Results:-}

We reviewed the records of a total of 100 primigravid patients aged between 12 and 16 years with labor in various phases, which were attended in the General Hospital of Campeche Finding that 57\% (57 patients) were 16 years; while $4 \%$ were 12 and 13 years old. Table 1

The resolution of the gestation of these patients was $68 \%$ (68 patients) vaginally, while the rest was by abdominal way $32 \%$ (32 patients). It should be mentioned that of $32 \%$ of patients with abdominal resolution of pregnancy only 4 of them $(12.5 \%)$ were due to preclampsia eclampsia.

During the months of study, we did not find significant changes from one month to the next in terms of the number of patients seen at the General Hospital; finding that the month with the lowest number of patients aged 12 to 16 years reported 10 and the highest number of 19 patients.

Finding also that the month of December presented a lower number of deliveries (5) compared with the previous months; being the one with the highest number of births, the month of August with 14. With regard to caesarean sections, there is also nosignificant variation in the study period, showing in July only 3 caesarean sections and in October, 8 caesarean sections.

Table 1:-Proportion of patients attended

\begin{tabular}{|l|c|c|c|}
\hline Month & Number of patients & Births & Cesareans \\
\hline July & 16 & 13 & 3 \\
\hline August & 18 & 14 & 6 \\
\hline September & 18 & 12 & 8 \\
\hline Octuber & 19 & 11 & 6 \\
\hline November & 19 & 13 & 5 \\
\hline December & 10 & 5 & 32 \\
\hline Total & 100 & 68 & \\
\hline
\end{tabular}

Source: Statistical record book of the gynecology and obstetrics service of H. G. C.

Table 2:-Distribution by ages

\begin{tabular}{|c|c|}
\hline Age & Number of patients \\
\hline 12 years & 2 \\
\hline 13 years & 2 \\
\hline 14 years & 10 \\
\hline 15 years & 29 \\
\hline 16 years & 57 \\
\hline
\end{tabular}

Source: Statistical record book of the gynecology and obstetrics service of H. G. C. 
Graphic 1:-Distribution of patients attended per month
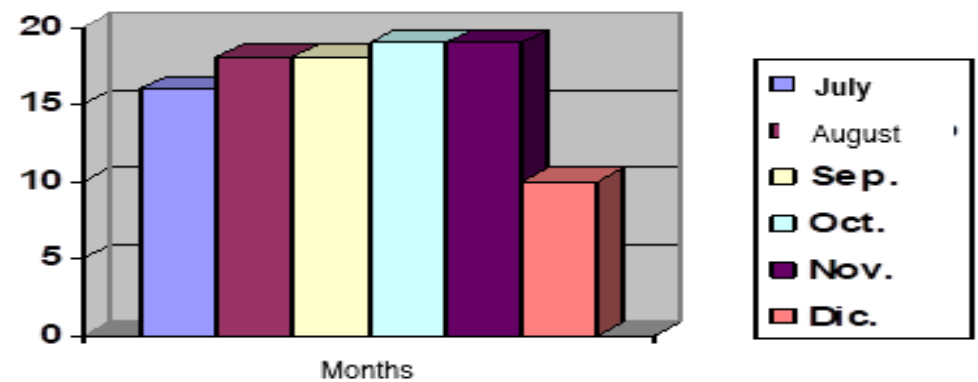

Source: Statistical record book of the gynecology and obstetrics service; Clinical File of G. H. C.

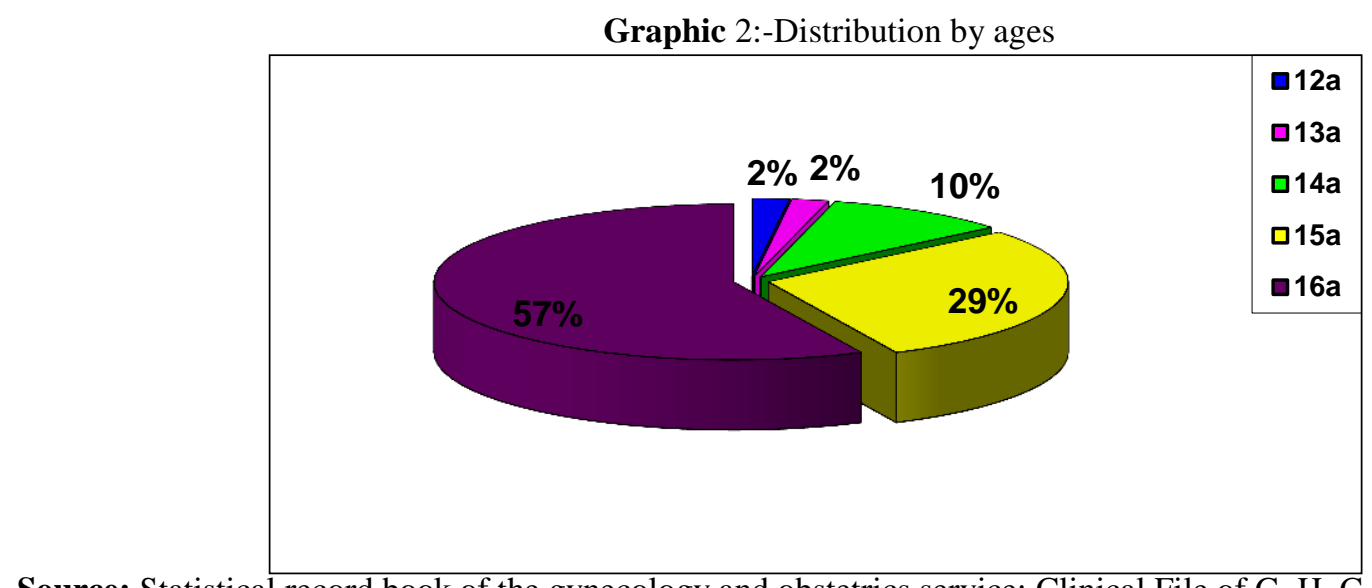

Source: Statistical record book of the gynecology and obstetrics service; Clinical File of G. H. C.

Graphic 3:-Percentage of biths and cesareans in these patients
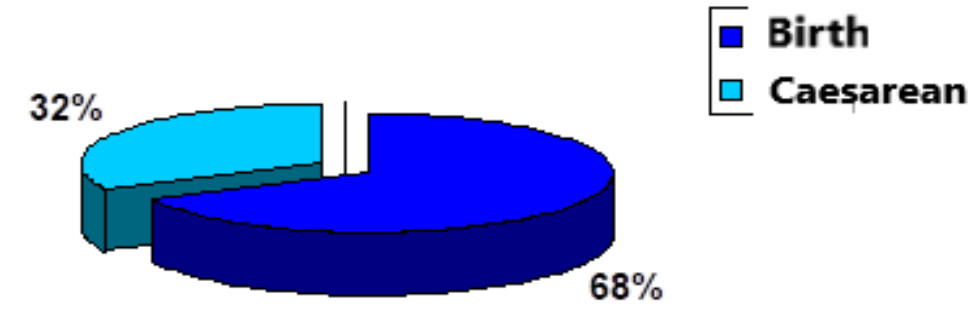

Source: Statistical record book of the gynecology and obstetrics service; Clinical File of G. H. C. 


\section{Conclusions:-}

In several studies it is reported that pregnancy in adolescents is complicated by multiple pathologies that culminate in their resolution by cesarean section. Given the immaturity of the organism at this stage it is logical to think that this is the most appropriate and safe route for the mother and the product, to the point that in some countries it is almost indicative of cesarean section being a teenage mother.

In the study carried out, we found that adolescent mothers had their products vaginally as a result of a low prevalence of observed obstetric complications.

In the complications of pregnancy are involved sociodemographic and ethnic factors that predispose the population groups to certain pathologies therefore these factors may be involved in the evolution of pregnancy in adolescents in our region and result in the low prevalence of Cesarean section as a method of pregnancy resolution.

Despite what was found in the study, it is necessary to continue promoting family planning as a means of population control, since many other factors are affected by pregnancy at an early age, we must take into account health, not only physical, but also emotional and even community health.

It would be convenient to emphasize in reproductive health campaigns because, as we mentioned in the study, the state has high rates of adolescent mothers occupying second place at the national level.

As far as we can conclude that in our State, adolescent patients are still being managed, they opt for a vaginal resolution of their pregnancy, despite what is dictated in the literature.

\section{Bibliographic References:-}

1. Escobar; Muñoz. Estudio Cualitativo de la experiencia de los padres adolescentes. Editorial Mediterráneo;1995. pag 112-114.

2. Diccionario Terminológico de Ciencias Medicas $12^{\mathrm{a}}$ Edición, Salvat editores, 1998 pag 86.

3. Diccionario de Ciencias Medicas Ilustrado, Stedman 25 Edición, Editorial Panamericana, 1993 pág. 48

4. Dañoso, Becker y Villaroel. Natalidad y Riesgo Reproductivo en adolescentes en Chile 1990-1999. Revista Panamericana de Salud Pública Vol. 14 no. 1 julio 2003, pag. 3-7

5. Villanueva LA, Pérez Fajardo. Características obstétricas de la adolescente embarazada. Revista Ginecología y Obstetricia de México 1999; volumen 67, pag. 34-41.

6. Advocates for Youth, Adolescent Sexual Health in Europe and the US, Why the Difference?, Washington DC, 2000 citado por Rodríguez Gabriela en Beneficios de la Educación Sexual. México, 2002

7. CONAPO:V Informe de avances del Programa Nacional de Población 1995-2000. México, 2000 (En linea) Disponible en www.conapo.com.mx (fecha de acceso 28 de septiembre de 2008)

8. Castillo, C. López, C. Muñoz, C. \& Rivera, J. Una aproximación a la conflictiva de la adolescente soltera embarazada Ed 1999. pag 35-42

9. Molina, R. Luengo, X. Guarda, P. González, E. \& Jara, G. (1991). Adolescencia, Sexualidad y Embarazo. Serie Científica Médica, 2,6-29

10. Toro Calzada. Embarazo en adolescentes. Comparación de complicaciones, peso, somatometría y calificación de Apgar con la población general. Revista Ginecología Obstetricia México, volumen 601992.

11. De la Garza Quintanilla C, Celaya- Juárez JA, Hernández Escobar C y col. La adolescente primípara. Revista Ginecología Obstetricia México. 1997; volumen 67

12. Simón Pereira L, Lira Plasencia J, Gracias Benítez C. Morbilidad materna en la adolescente embarazada. Ginecología Obstetricia México volumen 70; 2002 